\title{
MEMBANGUN BUDAYA ANTI-KORUPSI MELALUI PENINGKATAN PEMAHAMAN MENGENAI REGULASI DI BIDANG PEMBERANTASAN TINDAK PIDANA KORUPSI
}

\author{
Ade Adhari ${ }^{1}$, Fajar Dian Aryani ${ }^{2}$, Luisa Srihandayani ${ }^{3}$ dan Malvin Jati Kuncara Alam W ${ }^{4}$
}

\author{
${ }^{1}$ Fakultas Hukum, Universitas Tarumanagara, Jakarta \\ Email: adea@fh.untar.ac.id \\ ${ }^{2}$ Fakultas Hukum, Universitas Pancasakti Tegal, Tegal \\ Email: fajardi4n@gmail.com \\ ${ }^{3}$ Program Studi Magister Hukum, Universitas Diponegoro, Semarang \\ Email: luisas.15.07@gmail.com \\ ${ }^{4}$ Fakultas Hukum, Universitas Tarumanagara, Jakarta
}

\begin{abstract}
Corruption is a problem that is still being faced by the Indonesian people. Indonesia is also currently one of the countries with a high corruption rate. As a national problem, corruption is difficult to overcome because it is deeply rooted in various fields of life. Therefore, there is an urgency to build an anti-corruption culture. The cultural development must be started in a small scope, namely SMAN 17 Jakarta. The purpose of holding this activity is to increase understanding of the dangers of corruption for national development and various regulations on corruption prevention. The method of implementing PKM this time is done online by relying on a zoom platform. The stages of PKM implementation consist of identifying problem, drafting proposals, managing PKM implementation permits, implementing PKM, compiling PKM outputs, compiling PKM progress reports and preparing PKM final reports. The result of this PKM activity is to increase understanding of the policies to combat corruption that are needed to build an anti-corruption culture for students of SMAN 17 Jakarta. The conclusion from this activity is that it provides an understanding of the negative impact of corruption and various regulations on corruption prevention are useful for fostering enthusiasm to fight corruption in Indonesia. Through this understanding, students are expected to experience increased legal awareness about what actions are categorized as criminal acts of corruption.
\end{abstract}

Keywords: Anti-Corruption Culture, Corruption Eradication Law

\section{ABSTRAK}

Korupsi adalah permasalahan yang hingga saat ini masih dihadapi oleh Bangsa Indonesia. Indonesia pun saat ini menjadi salah satu negara dengan angka korupsi yang masih tinggi. Sebagai masalah nasional, korupsi sulit diatasi karena sudah mengakar dalam berbagai bidang kehidupan. Oleh sebab itu, terdapat urgensi untuk membangun budaya anti-korupsi. Pembangunan budaya tersebut harus dimulai dalam lingkup yang kecil yakni SMAN 17 Jakarta. Tujuan diselenggarakan kegiatan ini adalah untuk meningkatkan pemahaman tentang bahaya korupsi bagi pembangunan naisonal dan berbagai regulasi penanggulangan tindak pidana korpusi. Kegiatan pengabdian kepada masyarakat (PKM) kali ini dilakukan secara daring dengan mengandalkan platform zoom. Tahapan pelaksanaan PKM terdiri dari beberapa tahap yaitu tahap penggalian informasi permasalahan, penyusunan proposal, pengurusan izin pelaksanaan PKM, pelaksanaan PKM, penyusunan luaran PKM, penyusunan laporan kemajuan PKM dan penyusunan laporan akhir PKM. Hasil kegiatan PKM ini adalah meningkatnya pemahamanan tentang kebijakan penanggulangan tindak pidana korupsi yang dibutuhkan untuk membangun budaya anti korupsi para siswa SMAN 17 Jakarta. Kesimpulan dari hasil kegiatan PKM ini adalah pemberian pemahaman mengenai dampak negatif dari korupsi dan berbagai aturan penanggulangan korupsi bermafaat untuk menumbuhkan semangat untuk melawan korupsi di Indonesia. Melalui pemahaman tersebut, siswa diharapkan akan mengalami peningkatan kesadaran hukum tentang perbuatan apa saja yang dikategorikan sebagai tindak pidana korupsi.

Kata Kunci: Korupsi, Budaya Anti-Korupsi, UU Pemberantasan Tindak Pidana Korupsi

\section{PENDAHULUAN}

Mengawali bagian analisis situasi, tepat apabila mengutip apa yang disampaikan oleh Koutsoukis (2003) bahwa fenomena korupsi bukanlah hal yang baru. Masyarakat diseluruh dunia telah hidup dengan korupsi kecil-kecilan sejak dahulu kala. Indonesia menjadi salah satu negara yang angka korupsinya tinggi. Laporan Tahunan Komisi Pemberantasan Korupsi Tahun 2019 menyampaikan Score Indeks Persepsi Korupsi Indonesia adalah 40, dan ranking 86 dari 180 negara (Komisi Pemberantasan Korupsi, 2019). Bahkan pada Tahun 2020 mengalami penurunan menjadi 
peringkat 102 dunia (Ramadhan, 2021). Penuruan peringkat tersebut menunjukan, tingkat korupsi di Indonesia semakin buruk.

Komisi Pemberantasan Korupsi (KPK) sebagai lembaga tinggi negara telah menyatakan korupsi patut dinyatakan sebagai kejahatan luar biasa sehingga memerlukan penanganan khusus dalam hal pencegahan serta penindakannya. Sebagai sebuah gerakan yang terus didengungkan pada masa kini bahwa pemberantasan korupsi adalah harga mati karena dampaknya yang sangat besar dalam menyengsarakan bangsa dan negara (Adwirman, et al., 2014).

Adwirman, et. al (2014) mengemukakan bahwa korupsi memiliki berbagai dampak antara lain dampak ekonomi, dampak terhadap pelayanan kesehatan, dampak sosial dan kemiskinan masyarakat, dampak birokrasi pemerintah, dampak terhadap politik dan demokrasi, dampak terhadap penegakan hukum, dampak terhadap pertahanan dan keamanan, dan dampak kerusakan lingkungan.

Dampak inilah yang tentunya harus diatasi, apabila tidak diatasi tentunya korupsi sebagai penyakit di Indonesia akan semakin parah. Tiihonen (2003) memandang korupsi sebagai penyakit kekuasaan publik (a disease of public power) sekaligus indikasi pemerintahan yang buruk (indication of bad governance). Dengan demikian maraknya korupsi menandakan adanya pemerintahan yang buruk. Lebih jauh, terdapat pandangan bahwa korupsi di Indonesia begitu sulit diberantas karena sudah sangat membudaya, baik di kalangan lembaga legislatif, eksekutif, maupun yudikatif. Oleh sebab itu, menanamkan budaya antikorupsi dalam diri anak sejak usia dini menjadi hal yang sangat diperlukan, karena anak akan menjadi penerus estafet kepemimpinan. Apabila budaya antikorupsi tersebut sudah terpatri di dalam diri seluruh aparat penegak hukum dan seluruh lapisan masyarakat, maka budaya suap-menyuap yang merupakan salah satu bentuk dari tindak pidana korupsi dengan sendirinya akan menjadi tergeser bahkan sirna, sehingga tidak akan ada lagi istilah "membersihkan lantai dengan sapu yang kotor" dalam upaya pemberantasan tindak pidana korupsi di Indonesia (Sulastri, 2012).

Budaya anti-korupsi dengan demikian menjadi solusi ketika Undang-Undang Nomor 31 Tahun 1999 tentang Pemberantasan Tindak Pidana Korupsi jo. Undang-Undang Nomor 20 Tahun 2001 tentang Perubahan atas Undang-Undang Nomor 31 Tahun 1999 tentang Pemberantasan Tindak Pidana Korupsi (UU Tipikor) tidak mampu menurunkan tingkat korupsi di Indonesia. Dalam konteks ilmiah, persoalan budaya anti-korupsi menjadi sangat penting apabila dilihat dari sudut sistem hukum. Dimana, sistem hukum akan mampu memainkan perannya dengan baik dalam mengatasi korupsi apabila, seluruh sub-sistem tersebut dipersiapkan dengan baik. Tentunya, dalam kaitannya dengan penanggulangan korupsi, tidak hanya membangun subtansi hukum dengan menetapkan UU Tipikor, dan membentuk struktur hukum berupa adanya KPK melainkan lebih dari itu perlu membangun budaya hukum berupa budaya anti korupsi.

Dalam kaitannya dengan budaya anti-korupsi, dapat dikatakan "Perguruan Tinggilah yang memilki tanggung jawab moral untuk mencetak pemimpin-pemimpin bangsa yang bermoral di masa depan. Untuk menumbuhkan budaya anti korupsi di Indonesia (Saifulloh, 2017).

Budaya anti-korupsi ini tentunya harus dibangun mulai dari lingkup terkecil, salah satunya adalah sekolah. Hal ini dikarenakan Siswa sebagai agen perubahan (agent of change) masyarakat. Perbaikan masyarakat kearah masyarakat yang anti korupsi dengan demikian menjadi hal yang sangat krusial, terlebih para siswa merupakan generasi penerus bangsa yang nantinya akan memandu jalannya pemerintahan. Sehingga para siswa harus disiapkan sebaik mungkin agar menjadi agen-agen anti korupsi. 
Berdasarkan informasi yang disampaikan oleh SMAN 17 Jakarta selaku mitra pelaksana PKM kali ini didapatkan pemahaman bahwa:

1. Siswa belum memahami maksud atau tujuan utama pemberantasan tindak pidana korupsi;

2. Siswa belum memahami secara substansial berbagai regulasi yang mengatur tentang pemberantasan tindak pidana korupsi;

3. Siswa belum memahami secara menyeluruh bagaimana kebijakan pencegahan dan penanggulangan tindak pidana korupsi; dan

4. Siswa belum memahami perannya dalam mendukung program pemerintah dalam mencegah dan menanggulangi tindak pidana korupsi.

Beranjak pada uraian tersebutlah perlu diadakan pengabdian kepada masyarakat di SMAN. 17 Jakarta dengan mengangkat tema "Membangun Budaya Anti-Korupsi melalui Peningkatan Pemahaman Regulasi di Bidang Pemberantasan Tipikor".

\section{METODE PELAKSANAAN PKM}

Pelaksanaan pengabdian kepada masyarakat di SMAN 17 Jakarta diselenggarakan melalui berbagai tahapan yakni:

1. Tahapan Penggalian Informasi Permasalahan

2. Tahapan Penyusunan Proposal

3. Tahapan Pengurusan Izin Pelaksanaan PKM

4. Tahapan Pelaksanaan PKM

5. Tahapan Penyusunan Luaran PKM

6. Tahapan Penyusunan Laporan Kemajuan PKM

7. Tahapan Penyusunan Laporan Akhir PKM

Dalam kegiatan pelaksanaan pengabdian kepada masyarakat di SMAN 17 Jakarta, partisipasi mitra dalam berbagai bentuk yakni:

1. menyampaikan informasi tentang adanya pelaksanaan pengabdian kepada masyarakat di SMAN 17 Jakarta kepada siswa ke XI SMA 17;

2. mengadakan koordinasi dengan ketua kelas di masing-masing kelas XI SMA 17 untuk mengikuti kegiatan pengabdian kepada masyarakat; dan

3. menyusun absensi yang dibutuhkan pada saat elaksanaan pengabdian kepada masyarakat di SMAN 17 Jakarta.

\section{HASIL DAN PEMBAHASAN}

Budaya anti-korupsi dengan demikian menjadi solusi ketika UU Tipikor tidak mampu menurunkan tingkat korupsi di Indonesia. Dalam konteks ilmiah, persoalan budaya anti-korupsi menjadi sangat penting apabila dilihat dari sudut sistem hukum. Dimana, sistem hukum akan mampu memainkan perannya dengan baik dalam mengatasi korupsi apabila, seluruh sub-sistem tersebut dipersiapkan dengan baik. Tentunya, dalam kaitannya dengan penanggulangan korupsi, tidak hanya membangun subtansi hukum dengan menetapkan UU Tipikor, dan membentuk struktur hukum berupa adanya KPK melainkan lebih dari itu perlu membangun budaya hukum berupa budaya anti korupsi.

Dalam rangka membangun budaya anti korupsi dapat dimulai dengan menerangkan hal-hal mendasar perihal kebijakan penanggulangan korupsi yang ada di Indonesia. Hal ini dapat dimulai dengan menjelaskan berbagai perbuatan yang dikualifikasi sebagai tindak pidana korupsi dalam UU Tipikor. Dalam UU Tipikor perbuatan-perbuatan yang dikualifikasi sebagai tindak pidana korupsi antara lain: 
- Delik secara melawan hukum melakukan perbuatan memperkaya diri sendiri atau orang lain atau suatu korporasi yang dapat merugikan keuangan negara atau perekonomian negara (Pasal 2 ayat (1);

- Delik secara melawan hukum melakukan perbuatan memperkaya diri sendiri atau orang lain atau suatu korporasi yang dapat merugikan keuangan negara atau perekonomian negara, dilakukan dalam keadaan tertentu (Pasal 2 ayat (2);

- Delik dengan tujuan menguntungkan diri sendiri atau orang lain atau suatu korporasi, menyalahgunakan kewenangan, kesempatan atau sarana yang ada padanya karena jabatan atau kedudukan yang dapat merugikan keuangan negara atau perekonomian negara (Pasal 3);

- Delik memberi atau menjanjikan sesuatu kepada pegawai negeri atau penyelenggara negara dengan maksud supaya pegawai negeri atau penyelenggara negara tersebut berbuat atau tidak berbuat sesuatu dalam jabatannya, yang bertentangan dengan kewajibannya (Pasal 5 ayat (1) huruf a);

- Delik memberi sesuatu kepada pegawai negeri atau penyelenggara negara karena atau berhubungan dengan sesuatu yang bertentangan dengan kewajiban, dilakukan atau tidak dilakukan dalam jabatannya (Pasal 5 ayat (1) huruf b);

- Delik pegawai negeri atau penyelenggara negara yang menerima pemberian atau janji iscepidari pelaku yang memberi atau menjanjikan sesuatu kepada pegawai negeri atau penyelenggara negara dengan maksud supaya pegawai negeri atau penyelenggara negara tersebut berbuat atau tidak berbuat sesuatu dalam jabatannya, yang bertentangan dengan kewajibannya atau memberi sesuatu kepada pegawai negeri atau penyelenggara negara karena atau berhubungan dengan sesuatu yang bertentangan dengan kewajiban, dilakukan atau tidak dilakukan dalam jabatannya (Pasal 5 ayat (2));

- Delik memberi atau menjanjikan sesuatu kepada hakim dengan maksud untuk mempengaruhi putusan perkara yang diserahkan kepadanya untuk diadili (Pasal 6 ayat (1) huruf a);

- Delik memberi atau menjanjikan sesuatu kepada seseorang yang menurut ketentuan peraturan perundang-undangan ditentukan menjadi advokat untuk menghadiri sidang pengadilan dengan maksud untuk mempengaruhi nasihat atau pendapat yang akan diberikan berhubung dengan perkara yang diserahkan kepada pengadilan untuk diadili iscepi: (Pasal 6 ayat (1) huruf b);

- Delik hakim yang menerima pemberian atau janji dari pelaku yang memberi atau menjanjikan sesuatu kepada hakim dengan maksud untuk mempengaruhi putusan perkara yang diserahkan kepadanya untuk diadili (Pasal 6 ayat (2));

- Delik atau advokat yang menerima pemberian atau janji išpi dari pelaku yang memberi atau menjanjikan sesuatu kepada seseorang yang menurut ketentuan peraturan perundang-undangan ditentukan menjadi advokat untuk menghadiri sidang pengadilan dengan maksud untuk mempengaruhi nasihat atau pendapat yang akan diberikan berhubung dengan perkara yang diserahkan kepada pengadilan untuk diadili (Pasal 6 ayat (2));

- Delik pemborong, ahli bangunan yang pada waktu membuat bangunan, atau penjual bahan bangunan yang pada waktu menyerahkan bahan bangunan, melakukan perbuatan curang yang dapat membahayakan keamanan orang atau barang, atau keselamatan negara dalam keadaan perang is

- Delik setiap orang yang bertugas mengawasi pembangunan atau penyerahan bahan bangunan, sengaja membiarkan perbuatan curang sebagaimana dimaksud dalam huruf a (Pasal 7 ayat (1) huruf b); 
- Delik setiap orang yang pada waktu menyerahkan barang keperluan Tentara Nasional Indonesia dan atau Kepolisian Negara Republik Indonesia melakukan perbuatan curang yang dapat membahayakan keselamatan negara dalam keadaan perang (Pasal 7 ayat (1) huruf c);

- Delik setiap orang yang bertugas mengawasi penyerahan barang keperluan Tentara Nasional Indonesia dan atau Kepolisian Negara Republik Indonesia dengan sengaja membiarkan perbuatan curang sebagaimana dimaksud dalam huruf c (Pasal 7 ayat (1) huruf d);

- Delik Bagi orang yang menerima penyerahan bahan bangunan atau orang yang menerima penyerahan barang keperluan Tentara Nasional Indonesia dan atau Kepolisian Negara Republik Indonesia dan membiarkan perbuatan curang sebagaimana dimaksud dalam Pasal 7 ayat (1) huruf a atau huruf (Pasal 7 ayat (2));

- Delik pegawai negeri atau orang selain pegawai negeri yang ditugaskan menjalankan suatu jabatan umum secara terus menerus atau untuk sementara waktu, dengan sengaja menggelapkan uang atau surat berharga yang disimpan karena jabatannya, atau membiarkan uang atau surat berharga tersebut diambil atau digelapkan oleh orang lain, atau membantu dalam melakukan perbuatan tersebut (Pasal 8);

- Delik pegawai negeri atau orang selain pegawai negeri yang diberi tugas menjalankan suatu jabatan umum secara terus menerus atau untuk sementara waktu, dengan sengaja memalsu buku-buku atau daftar-daftar yang khusus untuk pemeriksaan administrasi (Pasal 9);

- Delik menggelapkan, menghancurkan, merusakkan, atau membuat tidak dapat dipakai barang, akta, surat, atau daftar yang digunakan untuk meyakinkan atau membuktikan di muka pejabat yang berwenang, yang dikuasai karena jabatannya (Pasal 10 huruf a);

- Delik membiarkan orang lain menghilangkan, menghancurkan, merusakkan, atau membuat tidak dapat dipakai barang, akta, surat, atau daftar tersebut (Pasal 10 huruf b);

- Delik membantu orang lain menghilangkan, menghancurkan, merusakkan, atau membuat tidak dapat dipakai barang, akta, surat, atau daftar tersebut (Pasal 10 huruf c);

- Delik pegawai negeri atau penyelenggara negara yang menerima hadiah atau janji padahal diketahui atau patut diduga, bahwa hadiah atau janji tersebut diberikan karena kekuasaan atau kewenangan yang berhubungan dengan jabatannya, atau yang menurut pikiran orang yang memberikan hadiah atau janji tersebut ada hubungan dengan jabatannya (Pasal 11);

- Delik pegawai negeri atau penyelenggara negara yang menerima hadiah atau janji, padahal diketahui atau patut diduga bahwa hadiah atau janji tersebut diberikan untuk menggerakkan agar melakukan atau tidak melakukan sesuatu dalam jabatannya, yang bertentangan dengan kewajibannya (Pasal 12 huruf a);

- Delik pegawai negeri atau penyelenggara negara yang menerima hadiah, padahal diketahui atau patut diduga bahwa hadiah tersebut diberikan sebagai akibat atau disebabkan karena telah melakukan atau tidak melakukan sesuatu dalam jabatannya yang bertentangan dengan kewajibannya (Pasal 12 huruf b);

- Delik hakim yang menerima hadiah atau janji, padahal diketahui atau patut diduga bahwa hadiah atau janji tersebut diberikan untuk mempengaruhi putusan perkara yang diserahkan kepadanya untuk diadili (Pasal 12 huruf c);

- Delik seseorang yang menurut ketentuan peraturan perundang-undangan ditentukan menjadi advokat untuk menghadiri sidang pengadilan, menerima hadiah atau janji, 
padahal diketahui atau patut diduga bahwa hadiah atau janji tersebut untuk mempengaruhi nasihat atau pendapat yang akan diberikan, berhubung dengan perkara yang diserahkan kepada pengadilan untuk diadili (Pasal 12 huruf d);

- Delik pegawai negeri atau penyelenggara negara yang dengan maksud menguntungkan diri sendiri atau orang lain secara melawan hukum, atau dengan menyalahgunakan kekuasaannya memaksa seseorang memberikan sesuatu, membayar, atau menerima pembayaran dengan potongan, atau untuk mengerjakan sesuatu bagi dirinya sendiri (Pasal 12 huruf e);

- Delik pegawai negeri atau penyelenggara negara yang pada waktu menjalankan tugas, meminta, menerima, atau memotong pembayaran kepada pegawai negeri atau penyelenggara negara yang lain atau kepada kas umum, seolah-olah pegawai negeri atau penyelenggara negara yang lain atau kas umum tersebut mempunyai utang kepadanya, padahal diketahui bahwa hal tersebut bukan merupakan utang (Pasal 12 huruf f);

- Delik pegawai negeri atau penyelenggara negara yang pada waktu menjalankan tugas, meminta atau menerima pekerjaan, atau penyerahan barang, seolah-olah merupakan utang kepada dirinya, padahal diketahui bahwa hal tersebut bukan merupakan utang (Pasal 12 huruf g);

- Delik pegawai negeri atau penyelenggara negara yang pada waktu menjalankan tugas, telah menggunakan tanah negara yang di atasnya terdapat hak pakai, seolah-olah sesuai dengan peraturan perundang-undangan, telah merugikan orang yang berhak, padahal diketahuinya bahwa perbuatan tersebut bertentangan dengan peraturan perundang-undangan (Pasal 12 huruf h);

- Delik pegawai negeri atau penyelenggara negara baik langsung maupun tidak langsung dengan sengaja turut serta dalam pemborongan, pengadaan, atau persewaan, yang pada saat dilakukan perbuatan, untuk seluruh atau sebagian ditugaskan untuk mengurus atau mengawasinya (Pasal 12 huruf i);

- tindak pidana korupsi yang nilainya kurang dari Rp 5.000.000,00 (lima juta rupiah) (Pasal 12A); dan

- Delik gratifikasi kepada pegawai negeri atau penyelenggara negara dianggap pemberian suap, apabila berhubungan dengan jabatannya dan yang berlawanan dengan kewajiban atau tugasnya (Pasal 12B ayat (1)).

Melalui pemahaman diatas, siswa diharapkan akan mengalami peningkatan kesadaran hukum tentang perbuatan apa saja yang dikategorikan sebagai tindak pidana korupsi. Selain itu, siswa perlu diberikan suatu pemahaman mengenai sanksi apa saja yang akan dikenakan kepada mereka yang melakukan tindak pidana korupsi. Dengan mengetahui berbagai sanksi tersebut diharapkan dapat menjadi dasar untuk mempengaruhi segi psikologis siswa untuk tidak melakukan tindak pidana korupsi di kemudian hari. Berikut ini adalah sanksi pidana yang tersedia dalam UU Tipikor:

- Pasal 2 ayat (1): penjara dengan penjara seumur hidup atau pidana penjara paling singkat 4 (empat) tahun dan paling lama 20 (dua puluh) tahun dan denda paling sedikit Rp200.000.000,00 (dua ratus juta rupiah) dan paling banyak Rp1.000.000.000,00 (satu milyar rupiah).

- Pasal 3: pidana penjara seumur hidup atau pidana penjara paling singkat 1 (satu) tahun dan paling lama 20 (dua puluh) tahun dan atau denda paling sedikit Rp50.000.000,00 (lima puluh juta rupiah) dan paling banyak Rp1.000.000.000,00 (satu milyar rupiah).

- Pasal 5: pidana penjara paling singkat 1 (satu) tahun dan paling lama 5 (lima) tahun dan atau pidana denda paling sedikit Rp 50.000.000,00 (lima puluh juta rupiah) dan paling banyak $\mathrm{Rp} 250.000 .000,00$ (dua ratus lima puluh juta rupiah) 
- Pasal 6: pidana penjara paling singkat 3 (tiga) tahun dan paling lama 15 (lima belas) tahun dan pidana denda paling sedikit Rp 150.000.000,00 (seratus lima puluh juta rupiah) dan paling banyak Rp 750.000.000,00 (tujuh ratus lima puluh juta rupiah);

- Pasal 7: pidana penjara paling singkat 2 (dua) tahun dan paling lama 7 (tujuh) tahun dan atau pidana denda paling sedikit Rp 100.000.000,00 (seratus juta rupiah) dan paling banyak Rp 350.000.000,00 (tiga ratus lima puluh juta rupiah);

- Pasal 8: pidana penjara paling singkat 3 (tiga) tahun dan paling lama 15 (lima belas) tahun dan pidana denda paling sedikit Rp 150.000.000,00 (seratus lima puluh juta rupiah) dan paling banyak Rp 750.000.000,00 (tujuh ratus lima puluh juta rupiah);

- Pasal 9: pidana penjara paling singkat 1 (satu) tahun dan paling lama 5 (lima) tahun dan pidana denda paling sedikit Rp 50.000.000,00 (lima puluh juta rupiah) dan paling banyak Rp 250.000.000,00 (dua ratus lima puluh juta rupiah);

- Pasal 10: pidana penjara paling singkat 2 (dua) tahun dan paling lama 7 (tujuh) tahun dan pidana denda paling sedikit Rp 100.000.000,00 (seratus juta rupiah) dan paling banyak Rp 350.000.000,00 (tiga ratus lima puluh juta rupiah);

- Pasal 11: pidana penjara paling singkat 1 (satu) tahun dan paling lama 5 (lima) tahun dan atau pidana denda paling sedikit Rp 50.000.000,00 (lima puluh juta rupiah) dan paling banyak Rp 250.000.000,00 (dua ratus lima puluh juta rupiah);

- Pasal 12: pidana penjara seumur hidup atau pidana penjara paling singkat 4 (empat) tahun dan paling lama 20 (dua puluh) tahun dan pidana denda paling sedikit Rp 200.000.000,00 (dua ratus juta rupiah) dan paling banyak Rp 1.000.000.000,00 (satu miliar rupiah);

- Pasal 12A: pidana penjara paling lama 3 (tiga) tahun dan pidana denda paling banyak Rp 50.000.000,00 (lima puluh juta rupiah).

- Pasal 12B: pidana penjara seumur hidup atau pidana penjara paling singkat 4 (empat) tahun dan paling lama 20 (dua puluh) tahun, dan pidana denda paling sedikit Rp 200.000.000,00 (dua ratus juta rupiah) dan paling banyak Rp 1.000.000.000,00 (satu miliar rupiah).

\section{KESIMPULAN DAN SARAN}

Kesimpulan yang dapat dikemukakan adalah para siswa SMAN 17 mendapatkan pemahaman baru mengenai berbagai peraturan perundang-undangan yang mengatur tentang pemberantasan tindak pidana korupsi. Saran yang dapat diajukan adalah perlu diupayakan kegiatan pemberian pemahaman mengenai budaya anti-korupsi lebih masih dikalangan pelajar di Indonesia.

Ucapan Terima Kasih (Acknowledgement)

Terima kasih kepada LPPM Untar atas pembiayaan pelaksanaan PKM dan kepada SMAN 17 Jakarta yang sudah berkenan menjadi mitra.

\section{REFERENSI}

Adwirman, et. al. (2014). Buku ajar pendidikan dan budaya anti-korupsi. Pusat Pendidikan dan Pelatihan Tenaga Kesehatan.

Sulastri, I. (Februari 2012). Perlunya menanamkan budaya antikorupsi dalam diri anak sejak usia dini. Mimbar Hukum, 24(1).

Koutsoukis, K. S. (2003). Political corruption in Greece dalam Martin J. Bull and James L. Newell corruption in contemporary politics. Palgrave Macmillan Ltd.

Komisi Pemberantasan Korupsi. (2019). Laporan tahunan KPK 2019.

Ramadhan, A. (28 Januari 2021). Indeks persepsi korupsi Indonesia pada 2020 turun jadi 37, peringkat 102 dunia. Kompas. https://nasional.kompas.com/read/2021/01/ 28/14120521/indeks-persepsi-korupsi-indonesia-pada-2020-turun-jadi-37-peringkat-102di. 
Saifulloh, P. P. A. (2017). Peran perguruan tinggi dalam menumbuhkan budaya anti korupsi di Indonesia. Jurnal Hukum dan Pembangunan, 47(4), 459-476.

Tiihonen, S. (2003). Central government corruption in historical perspective dalam seppo tiihonen the history of corruption in central government. IIAS.

Undang-Undang Nomor 31 Tahun 1999 tentang Pemberantasan Tindak Pidana Korupsi.

Undang-Undang Nomor 20 Tahun 2001 tentang Perubahan atas Undang-Undang Nomor 31 Tahun 1999 tentang Pemberantasan Tindak Pidana Korupsi 